\title{
Intakes of fruit and vegetables in Irish children (5-12 years)
}

It is recommended in Ireland that children over 5 years of age consume $400 \mathrm{~g}$ or five $(80 \mathrm{~g})$ servings of fruit and vegetables per day, including no more than $150 \mathrm{ml}$ of unsweetened fruit juice or smoothies as one serving ${ }^{(1,2)}$. The aim of this analysis was to estimate fruit and vegetable intakes, including those from composite foods, in Irish children aged 5-12 years using data from the National Children's Food Survey (NCFS) (2003-2004) which used a 7-d weighed food diary to collect detailed food and beverage intake data from a representative sample of 594 children (www.iuna.net). Of 1945 food codes consumed during the survey period, 860 had a fruit/vegetable component. These included discrete fruit and vegetables, fruit and vegetables from composite foods, $100 \%$ fruit juices and fruit in smoothies, squashes and fruit juice drinks. The fruit and/or vegetables content in each food code was estimated using standard recipes from McCance and Widdowson's, The Composition of Foods ${ }^{(3)}$, the Irish food composition database ${ }^{(4)}$ and manufacturers' product information. Inedible portions of fruit and vegetables were excluded ${ }^{(4)}$. SPSS ${ }^{\odot}$ v22 was used to calculate mean daily intake (MDI) of fruit and vegetables and percentage of the population meeting recommendations.

\begin{tabular}{|c|c|c|c|c|c|c|c|c|c|}
\hline & \multicolumn{3}{|c|}{ Total Population } & \multicolumn{3}{|c|}{ Male } & \multicolumn{3}{|c|}{ Female } \\
\hline & $\begin{array}{c}\text { All } \\
n 594\end{array}$ & $\begin{array}{l}5-8 \mathrm{y} \\
n 296\end{array}$ & $\begin{array}{c}9-12 \text { y } \\
n 298\end{array}$ & $\begin{array}{c}\text { All } \\
n 293\end{array}$ & $\begin{array}{l}5-8 \text { y } \\
n 144\end{array}$ & $\begin{array}{c}9-12 \mathrm{y} \\
n 147\end{array}$ & $\begin{array}{c}\text { All } \\
n 301\end{array}$ & $\begin{array}{l}5-8 \text { y } \\
n 152\end{array}$ & $\begin{array}{c}9-12 \text { y } \\
n 151\end{array}$ \\
\hline & \multicolumn{9}{|c|}{ Mean Intake (g/d) } \\
\hline Total Fruit & 169 & 172 & 166 & 161 & 162 & 159 & 176 & 181 & 172 \\
\hline Discrete Fruit & 58 & 62 & 53 & 57 & 64 & 51 & 58 & 61 & 55 \\
\hline Fruit in composite foods & 9 & 9 & 9 & 10 & 9 & 10 & 9 & 8 & 9 \\
\hline Fruit components in squashes \& fruit juice drinks & 16 & 16 & 17 & 18 & 17 & 18 & 15 & 15 & 15 \\
\hline Fruit from smoothies & $0 \cdot 5$ & $0 \cdot 5$ & $0 \cdot 5$ & $0 \cdot 2$ & 0 & $0 \cdot 3$ & $0 \cdot 9$ & $1 \cdot 1$ & $0 \cdot 7$ \\
\hline $100 \%$ fruit juices & 85 & 84 & 86 & 76 & 72 & 79 & 94 & 95 & 92 \\
\hline Total Vegetables & 60 & 56 & 64 & 61 & 56 & 67 & 59 & 56 & 62 \\
\hline Discrete Vegetables & 29 & 28 & 30 & 29 & 29 & 29 & 28 & 27 & 30 \\
\hline Vegetables in composite foods & 31 & 28 & 35 & 32 & 27 & 37 & 31 & 29 & 32 \\
\hline \multirow[t]{2}{*}{ Total fruit and vegetables } & 229 & 228 & 230 & 222 & 218 & 226 & 235 & 237 & 234 \\
\hline & \multicolumn{9}{|c|}{$\%$ of children } \\
\hline$\% \geq 400 \mathrm{~g} / \mathrm{d}$ with unlimited fruit juice & $10 \cdot 8$ & $10 \cdot 1$ & $11 \cdot 4$ & $9 \cdot 3$ & $7 \cdot 6$ & $10 \cdot 9$ & $12 \cdot 2$ & $12 \cdot 5$ & $11 \cdot 9$ \\
\hline$\% \geq 5$ servings/day* & $4 \cdot 0$ & $3 \cdot 7$ & $4 \cdot 4$ & 4.5 & $4 \cdot 2$ & 4.8 & 3.6 & $3 \cdot 3$ & $4 \cdot 0$ \\
\hline
\end{tabular}

*Servings defined by The Healthy Eating Guidelines (including $\leq 150 \mathrm{ml}$ of unsweetened fruit juice/smoothies as one serving where consumed) ${ }^{(2)}$

The MDI of total fruit and vegetables from all sources in the population was $229 \mathrm{~g} / \mathrm{d}$ (equivalent to 2.9 servings) with $10 \cdot 8 \%$ of children having intakes $\geq 400 \mathrm{~g}$ per day. When the contribution of unsweetened fruit juice and smoothies was limited to no more than $150 \mathrm{ml} / \mathrm{d}$, the MDI of fruit and vegetables was 2.6 servings ( 1.8 from fruit and 0.8 from vegetables) with just $4 \%$ of children meeting the recommended intake of 5 servings per day, while $15 \%$ had intakes $\geq 4$ servings per day and $36 \% \geq 3$ servings per day. Composite foods contributed $31 \mathrm{~g} / \mathrm{d}(52 \%)$ of total vegetable intakes but were not as important for fruit (5\% of intake). In conclusion, this study has shown that intakes of fruit and vegetables in young children are not meeting the current recommendations and that composite food and dishes should be included in estimates of intakes, particularly for vegetables. These findings may be useful for developing strategies to increase fruit and vegetable intakes in Irish children.

This research was funded by the Irish Department of Agriculture, Food and the Marine under the project 'National Children's Food Consumption Survey II' $(15 / F / 673)$

1. Food Safety Authority of Ireland (2011) FSAI. Dublin, Ireland. https://www.fsai.ie/recommendationsforhealthyeatingguidelinesinireland.html.

2. Department of Health (2016) https://www.healthpromotion.ie/hp-files/docs/HPM00796.pdf.

3. Food Standards Agency (2002) Royal Society of Chemistry. Cambridge.

4. Black LJ, Ireland J, Moller A et al. (2011) J Food Compos Anal 24(7), 1017-1023. 